\title{
THE INFLUENCE OF SCREW TYPE, ALLOY AND CYLINDER POSITION ON THE MARGINAL FIT OF IMPLANT FRAMEWORKS BEFORE AND AFTER LASER WELDING
}

\author{
INFLUENCIA DO TIPO DE PARAFUSO, LIGA E DA POSIÇÃO DO CILINDRO NA \\ ADAPTAÇÃO MARGINAL DAS INFRA-ESTRUTURAS SOB IMPLANTES ANTES E APÓS A \\ SOLDAGEM A LASER
}

Daniela CASTILIO ${ }^{1}$, Ana Paula Ribeiro do Vale PEDREIRA², Paulo Henrique Orlato ROSSETTI ${ }^{3}$, Leylha Maria Nunes ROSSETTI ${ }^{3}$, Wellington Cardoso BONACHELA ${ }^{4}$

\begin{abstract}
1- DDS, MSc, Graduate Student, Department of Dental Materials, Bauru Dental School, University of São Paulo, Brazil.
2- DDS, Graduate Student, Department of Prosthodontics, Bauru Dental School, University of São Paulo, Brazil.

3- DDS, MSc, Graduate student, Department of Prosthodontics, Bauru Dental School, University of São Paulo, Brazil.

4- DDS, MSc, PhD, Associate Professor, Department of Prosthodontics, Bauru Dental School, University of São Paulo, Brazil.

Corresponding address: Wellington Cardoso Bonachela - Departamento de Prótese - Al. Dr. Octávio Pinheiro Brisola, 9-75

Cep.: 17012-101 Bauru - SP - e-mail: wbonach@fob.usp.br
\end{abstract}

Received: December 06, 2004 - Modification: May 18, 2005 - Accepted: January 19, 2006

\begin{abstract}
$M$

isfit at the abutment-prosthetic cylinder interface can cause loss of preload, leading to loosening or fracture of gold and titanium screws. Objectives: To evaluate the influence of screw type, alloy, and cylinder position on marginal fit of implant frameworks before and after laser welding. Methods: After Estheticone-like abutments were screwed to the implants, thirty plastic prosthetic cylinders were mounted and waxed-up to fifteen cylindrical bars. Each specimen had three interconnected prosthetic components. Five specimens were one-piece cast in titanium and five in cobalt-chromium alloy. On each specimen, tests were conducted with hexagonal titanium and slotted gold screws separately, performing a total of thirty tested screws. Measurements at the interfaces were performed using an optical microscope with $5 \mu \mathrm{m}$ accuracy. After sectioning, specimens were laser welded and new measurements were obtained. Data were submitted to a four-way ANOVA and Tukey's multiple comparisons test $(\alpha=0.05)$. Results: Slotted and hexagonal screws did not present significant differences regarding to the fit of cylinders cast in titanium, either in one-piece casting framework or after laser welding. When slotted and hexagonal screws were tested on the cobalt-chromium specimens, statistically significant differences were found for the one-piece casting condition, with the slotted screws presenting better fit (24.13 $\mu \mathrm{m})$ than the hexagonal screws $(27.93 \mu \mathrm{m})$. Besides, no statistically significant differences were found after laser welding. Conclusions: 1) The use of different metal alloys do exert influence on the marginal fit, 2) The slotted and hexagonal screws play the exclusive role of fixing the prosthesis, and did not improve the fit of cylinders, and 3) cylinder position did not affect marginal fit values.

uniterms: Gold screw; Titanium screw; Laser welding; Osseointegrated implants.
\end{abstract}

\footnotetext{
RESUMO

A

desadaptação na interface abutment-cilindro protético pode causar perda da pré-carga, levando ao afrouxamento ou fratura dos parafusos de ouro e titânio. Objetivos: Avaliar a influência do tipo de parafuso, liga e posição do cilindro na adaptação marginal de infra-estruturas sobre implante antes e após a soldagem a laser. Métodos: Após os abutments do tipo Estheticone serem aparafusados nos implantes, trinta cilindros protéticos de plástico foram montados e encerados com 15 barras cilíndricas. Cada espécime possuía três componentes protéticos interconectados. Cinco espécimes foram fundidos em monobloco com liga de titânio e liga de cobalto-crômio. Em cada espécime, os testes foram conduzidos com parafusos hexagonais de titânio e com parafusos de ouro com fenda, separadamente, num total de 30 parafusos testados. As medidas nas interfaces foram feitas com microscópio óptico com $5 \mu \mathrm{m}$ de precisão. Após o seccionamento, os espécimes foram soldados a laser e novas medidas obtidas. Os dados foram submetidos para análise com os testes ANOVA a quatro critérios e Tukey para comparações múltiplas $(\alpha=0,05)$. Resultados: Os parafusos com fenda e hexágono não apresentaram diferenças significantes independente da adaptação dos cilindros fundidos em titânio, tanto em monobloco como após a soldagem a laser. Quando os parafusos com hexágono e fenda foram testados nos espécimes de cobalto-crômio, diferenças estatisticamente significantes foram encontradas na condição monobloco, com os parafusos fendidos apresentando melhor adaptação $(24,13 \mu \mathrm{m})$ do que os com hexágono $(27,93 \mu \mathrm{m})$. Além disso, nenhuma diferença significante foi encontrada após a soldagem a laser. Conclusões: 1) O uso de diferentes ligas metálicas exerce influência nos resultados, 2) Os parafusos com hexágono e fenda somente possuem o papel de fixar a prótese, e não melhoram a adaptação dos cilindros e 3) a posição do cilindro não afetou os valores de adaptação marginal. unitermos: Parafuso de ouro; Parafuso de titânio; Soldagem a laser; Implantes osseointegrados.
} 


\section{INTRODUCTION}

The osseointegration between titanium and bone has been investigated and confirmed by anatomical and histological studies ${ }^{1}$. However, the clinical success of implant-supported restorations depends on several biomechanical factors. The precision between machined parts is one of them ${ }^{7,8}$. High precision components are necessary to provide stability, resistance and excellent esthetical results.

Nowadays, titanium is very important as a restorative material due to its mechanical resistance, biocompatibility, and inertness. In addition, it is the only metal that can be soldered intra-orally ${ }^{9,11}$. Furthermore, it has adequate thickness to provide support for the dental porcelain ${ }^{19}$.

Nevertheless, Co-Cr alloys have been advocated in dentistry for more than 60 years to cast removable partial dentures. These alloys have low density values, good resistance to tarnish and erosion, low cost and high elastic modulus $^{2,3}$. However, they demonstrate poor castability, difficulties in finish and polishing, and great shrinkage after casting procedures ${ }^{1}$.

A study showed that one-piece casting FPDs have predictable degree of distortion $(100 \mu m)^{27}$. In this sense, any attempts to reduce non-axial forces to the surrounding bone could be advantageous. One paradigm in implant prosthodontics is to obtain passive fit between abutment and prosthetic cylinders incorporated into the framework ${ }^{18,20,23,24,26}$ when gold alloys are used. To solve this problem, laser welding procedures have been proposed since 1987 as an alternative method for implant-supported prostheses ${ }^{8}$. Thus, pre-selected parts can be joined together with less residual stresses ${ }^{5,6,12,22,29,30}$.

Even thus, screw loosening has been observed either in single or extensive implant-supported restorations. It is not certain to what extent the screw material or its configuration could exert some influence at the abutment-cylinder interface. Also, the interaction between laser welding and screw material on marginal fit results is unknown.

In this way, the purpose of this study was to evaluate the influence of screw type, alloy, and cylinder position on the marginal fit before and after laser welding procedure.

\section{PROPOSITION}

The present study evaluated, before and after laser welding:

1- Marginal fit at abutment-prosthetic cylinder interface, cast in titanium and Co-Cr alloys;

2- Marginal fit at abutment-prosthetic cylinder interface, with different screw types (slotted or hexagonal);

3- Marginal fit at abutment-prosthetic cylinder interface, according to the cylinder position.

\section{MATERIALAND METHODS}

The master model used in this study was constructed as follows: three implants with external hexagon design, regular platform (10mm-long, 3.75mm-diameter; Conexão Sistemas de Prótese - São Paulo- SP - Brazil) were embedded with self-cured acrylic resin (Artigos Odontológicos Clássico LTDA, São Paulo) in a rectangular metallic base (40x10x15mm) (Figure 1). Estheticone-like abutments (22CNBA 3mm, Conexão Sistemas de Prótese - São Paulo - SP Brazil) were screwed on each implant with a $20 \mathrm{Ncm}$ torque (Nobelpharma - Torque Controller ${ }^{\mathrm{TM}}$ Gotemburg, Sweden).

To obtain prosthetic frameworks, plastic cylinders were screwed to the abutments. Then, cylindrical bars were attached to the plastic components (105CNB Conexão Sistemas de Prótese - São Paulo - SP - Brazil). To verify the influence of alloy type on marginal fit, wax patterns were divided into two groups: G1- Titanium alloy (5 specimens) (Rematitan - Dentaurum Pforzheim - Germany) and G2Cobalt-Chromium alloy (5 specimens) (Rexillium N.B.F. Jeneric/Pentron Incorporated). Both alloys were invested and cast according to manufacturer's instructions. Titanium was cast in a specific atmosphere to avoid bulk contamination. Samples were divested and internally cleaned with $45 \%$ hydrofluoric acid. To protect external margins from scratching after cleaning, abutment analogs were screwed and frameworks blasted with glass beads particles.

The prosthetic frameworks were placed in the master model with a $10 \mathrm{Ncm}$ torque. The cylinders were named C1, $\mathrm{C} 2$ and C3. To verify the influence of screw type on marginal fit, slotted (S) and hexagonal $(\mathrm{H})$ screws were tested (Figure 2). Thus, four subgroups were formed: G1-S, G1-H, G2-S and G2-H. Analysis of marginal fit in each subgroup was performed with a digital microscope (Mitutoyo, Tokyo, Japan) (Figure 3A,B). Measurements were made at abutmentcylinder interface. Each point was measured 3 times, which resulted in 12 measurements. Final marginal fit corresponded to the overall mean of these values.

To verify the influence of laser welding on marginal fit, frameworks were cross-sectioned with a carborundum disc under water cooling (ref.9500.900.220.GEBR - Brasseler Gmbh \& Co.KG, Lemgo, Germany) at low speed rotation. The separated parts had their marginal fit as already described and were screwed again. A laser welding machine

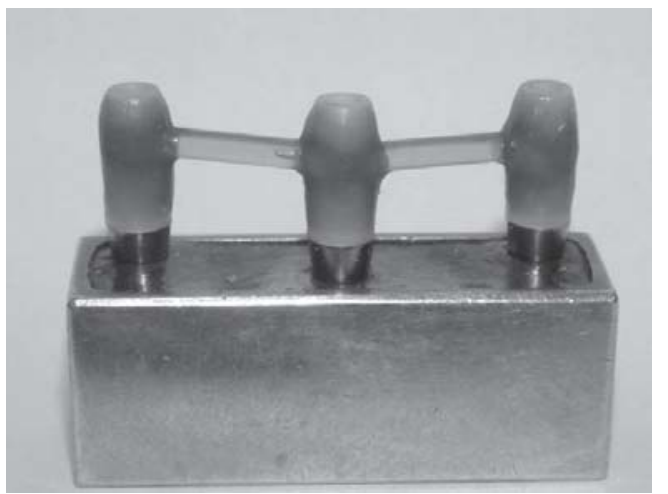

FIGURE 1- Waxed-up bar incorporating prosthetic cylinders 
(DL 2002s - Laser Dentaurum Pforzheim, Germany) was used to obtain the solder joints. The laser weld was scheduled to $300 \mathrm{~V} / 10 \mathrm{msec}$ at a focus zero frequency. After laser welding, new marginal fit measurements were performed using the same criteria in both subgroups.

\section{Statistical analysis}

The Kolmogorov-Smirnov test was used to verify homogeneity in both subgroups. Data were submitted to a four-way ANOVA analysis (alloy, cylinders, laser welding, and screws) to identify significant differences among groups $(\alpha=0.05)$. In the event that differences were found, a Tukey's multiple comparisons test was performed to determine which groups were similar or different $(\alpha=0.05)$.

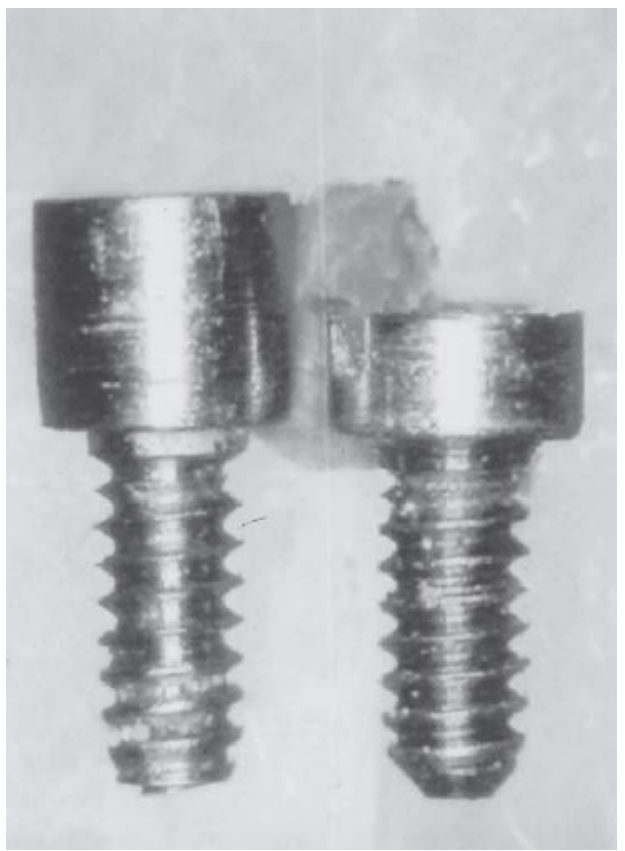

FIGURE 2- Titanium and gold screw general configuration

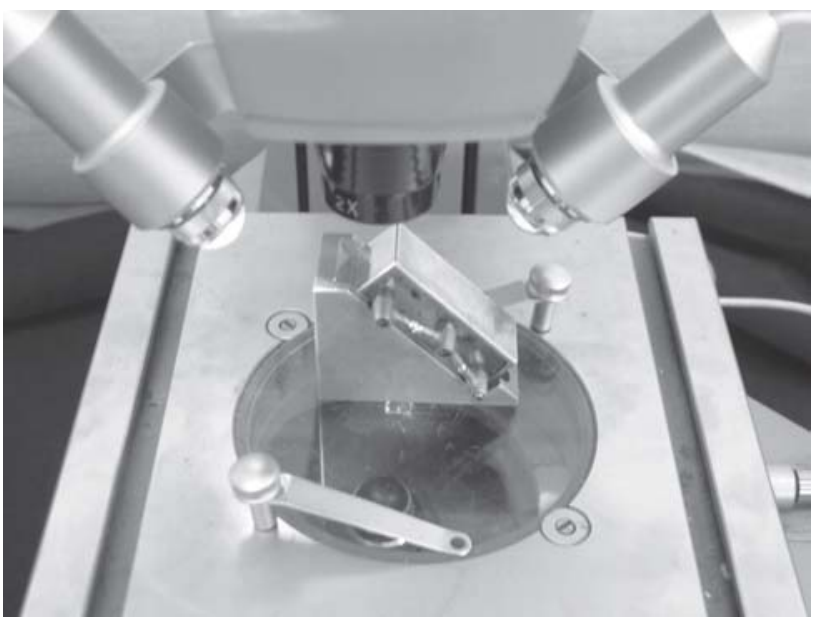

FIGURE 3A- Specimen positioned in the microscope for analysis

\section{RESULTS AND DISCUSSION}

One of the greatest difficulties in implant-supported prosthodontics is to obtain precise fit when the metal framework is screwed onto the abutments. This primary goal has been the subject of several studies s,15,16,21,25,28 $^{\text {. According }}$ to Carlsson and Carlsson ${ }^{1}$, an implant prosthesis with passive fit means that it can be screwed without tensile stress transmission to the implants or associated components. However, there are several designs and materials for prosthetic screws. Manufacturers state that screws are interchangeable, regardless of their material or mechanical properties. In addition, prosthetic screws that generate higher torque values are less prone to fracture or deformation; however, this assumption was not confirmed under clinical conditions. The main objective of this work was to answer the question: what really would be the influence of different screws, alloys and cylinder position on the marginal fit before and after laser welding?

One limitation of this study could be the generated torque applied to the screws; however, a torque controller device was used since manual torque is prone to fatigue operator. Machining defects in the thread configuration also influence final results and irregular screws were discarded before the experiment begins.

In the present study, non-statistically significant differences were observed at abutment-prosthetic cylinder interface when the screw type was the source of variation. For the marginal fit values, statistically significant differences were found between cast material (titanium and Co-Cr alloys), and between cast techniques (one-piece castings and laser welding procedures) (Table 1).

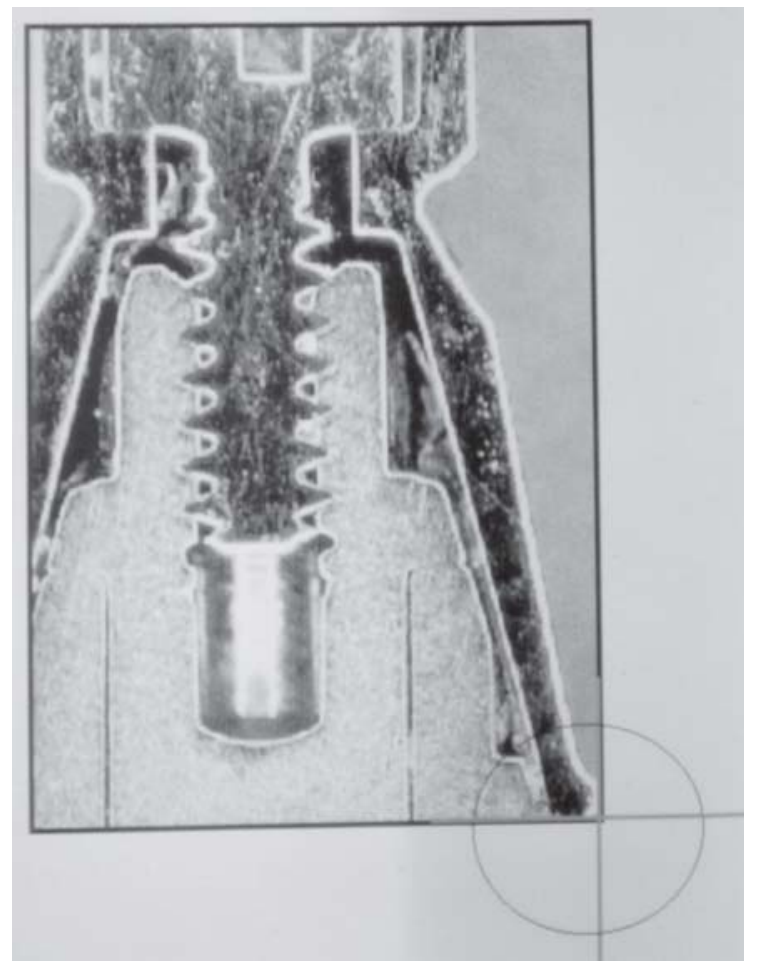

FIGURE 3B- Cross-sectional view of points for measurement 
Marginal fit values for slotted screws were not different with or without laser welding (Table 1), but significant differences were found for hexagonal screws in the same conditions. Slotted and hexagonal screws did not present significant differences regarding to the fit of cylinders cast in titanium, either in one-piece casting framework or after laser welding. When slotted and hexagonal screws were tested on the cobalt-chromium specimens, statistically significant differences were found for the one-piece casting framework condition, with the slotted screws presenting better fit $(24.13 \mu \mathrm{m})$ than the hexagonal screws $(27.93 \mu \mathrm{m})$. Besides, no statistically significant difference was found after laser welding. This observation is in accordance with previous studies that recommend sectioning and soldering to achieve better fit ${ }^{17,22,26}$. Furthermore, slotted gold screws have an elastic modulus two times lower than the titanium screws. This condition generates larger deformations at the first screw threads to achieve higher pre-load values.

Significant differences were observed for both screws when one-piece castings were obtained. Thus, these differences are due to casting techniques and not to the screws. For example, titanium has to be cast in special atmospheres (e.g., noble gases) given its high oxide formation due to contamination. Similarly, Co-Cr alloy provided higher marginal fit values compared to titanium alloy. This can be explained by differences in castability of both alloys that are not related to the screw configuration. Even thus, the Co-Cr alloys have an important role in dentistry due to their low $\operatorname{cost}^{14,15}$. An acceptable fit has

TABLE 1- Marginal fit values before and after laser welding $(\mu \mathrm{m})$

\begin{tabular}{llll} 
Cylinder & Subgroups & Before & After \\
\hline C1 & G1-S & $25.08+6.30 \mathrm{a}$ & $15.83+4.57 \mathrm{a}$ \\
C2 & & $25.99 \pm 8.01$ & $19.49 \pm 4.30$ \\
C3 & & $24.83 \pm 3.73 \mathrm{~b}$ & $15.75 \pm 3.60 \mathrm{~b}$ \\
& & & \\
C1 & G1-H & $24.99+4.27$ & $19.08+6.86$ \\
C2 & & $22.80 \pm 2.70$ & $18.99 \pm 4.86$ \\
C3 & & $25.33 \pm 6.90$ & $16.33 \pm 2.86$ \\
& & & \\
C1 & G2-S & $22.91+3.97$ & $23.91+4.52$ \\
C2 & & $25.33 \pm 3.02$ & $21.41 \pm 4.60$ \\
C3 & & $24.16 \pm 2.58$ & $22.83 \pm 3.10$ \\
& & & \\
C1 & G2-H & $29.83+7.66$ & $24.83+6.07$ \\
C2 & & $26.74 \pm 3.54$ & $21.07 \pm 5.39$ \\
C3 & & $27.24 \pm 4.96 \mathrm{C}$ & $19.33 \pm 3.12 \mathrm{c}$ \\
\hline
\end{tabular}

$\mathrm{C}=$ cylinder, $\mathrm{S}=$ slotted screw, $\mathrm{H}=$ hexagonal screw, $\mathrm{G} 1=$ titanium alloy. G2 = cobalt-chromium alloy

Small letters represent statiscally significant differences in the same line $(\alpha<0.05)$ been observed when Co-Cr is cast for implant frameworks ${ }^{13,17,31}$

JEMT, et al. ${ }^{16}$ suggested that acceptable marginal fit levels were less than $150 \mathrm{~mm}$. Moreover, even with the little range of marginal fit values (16 to $29 \mathrm{~mm}$ ) (Table 1 ) obtained, gaps with $3 \mathrm{~mm}$ or less are harmful since a number of microorganisms have this diameter. Potential plaque accumulation in these areas produces one type of electrolyte, and the saliva provides another electrolyte at the occlusal surface. Therefore, electrochemical corrosion (concentration cell or crevice corrosion) occurs, with preferential attack of the metal surface occurring underneath the layer of food debris ${ }^{29}$. In the same way, stress and pitting corrosion occur in chromium alloys due to chloride ions. The corrosion products can spread into the periimplant sulcus leading to inflammation, bone loss, and lack of osseointegration. Regardless of values obtained, adequate oral hygiene procedures are mandatory to guarantee longterm stability of prosthesis.

\section{CONCLUSIONS}

1- The use of different metal alloys do exert influence on the marginal fit;

2- The slotted and hexagonal screws play the exclusive role of fixing the prosthesis, and did not improve the fit of the cylinders;

3- Cylinder position did not affect marginal fit values.

\section{REFERENCES}

1- Carlsson B, Carlsson, GE. Prosthodontic complications in osseointegrated dental implant treatment. Int J Oral Maxillofac Implants. 1994,9:90-4.

2- Chao Y, Zarb GA, Judes H. A study into the use of chromiumcobalt alloy for constructing the framework for osseointegrated. Clin Mater. 1988;3:309-15.

3- Craig RG. Restorative dental materials. St Louis: Mosby; 1989.

4- Goheen KL, Vermilyea SG, Vossoughi J, Agar JR. Torque generated by handheld screwdrivers and mechanical torque devices for osseointegrated implants. Int J Oral Maxillofac Implants. 1994;9:14955 .

5- Goll GE. Production of accurately fitting full-arch implant frameworks: part I - clinical procedures. J Prosthet Dent. 1991;66:377-84

6- Gordon TE, Smith DL. Laser welding of prosthesis - an initial report J Prosthet Dent. 1970;24:472-6.

7- Guichet DL, Caputo AA, Choi H, Sorensen JA. Passivity of fit and marginal opening in screw or cement-retained implant fixed partial designs. Int J Oral Maxillofac Implants. 2000;15:239-46.

8- Gyllenram F. Handling and hardware. The two ultimate parameters for a clinically acceptable fit. Nobelpharma News. 1994;8:4-5.

9- Haney SC, Meiers, JC. In vitro study of intraoral welding procedures for pure titanium. Quintessence Int. 1996;27:841-7. 
10- Hellden LB, Dérand T. Description and evaluation of a simplified method to achieve passive fit between cast titanium frameworks and implants. Int J Oral Maxillofac Implants. 1998;13:190-6.

11- Hurska AR. Intraoral welding of pure titanium. Quintessence Int. 1987; 18:683-8.

12- Hulling JS, Clark RE. Comparative distortion in three-unit fixed prostheses joined by laser welding, conventional soldering or casting in one-piece. J Dent Res. 1977;56:128-34.

13- Hultersstrom M, Nilsson U. Cobalt-chromium as a framework material in implant-supported fixed prostheses: a 3-year follow-up. Int J Oral Maxillofac Implants. 1994;9:449-54.

14- Jaarda MJ, Razzoog ME, Gratton DG. Ultimate tensile strength of five interchangeable prosthetic retaining screws. Implant Dent. 1996;5:16-9.

15- Jemt $\mathrm{T}$. Three-dimensional distortion of gold alloy casting and welded titanium frameworks. Measurements of the precision on fit between completed implant prostheses and master casts in routine edentulous situations. J Oral Rehabil. 1995;22:557-64.

16- Jemt T, Rubenstein JE, Carlsson L, Lang BR. Measuring fit and the implant prosthodontic interface. J Prosthet Dent. 1996;75:31424.

17- Kallus T, Bessing C. Loose gold screws frequently occur in fullarch fixed prostheses supported by osseointegrated implants after 5 years. Int J Oral Maxillofac Implants. 1994;9:169-78.

18- Kan JY, Rungcharassaeng K, Bohsali K, Goodacre CJ, Lang BR. Clinical methods for evaluating implant framework fit. J Prosthet Dent. 1999;81:7-13.

19- Kano SC. Disajustment of prosthetic components using different alloys. J Dent Res. 1995;74:806.

20- May KB, Edge MJ, Russell MM, Razzoog ME, Lang BR. The precision of fit at the implant prosthodontic interface. J Prosthet Dent. 1997;77:497-502.

21- McCartney JW, Doud R. Passive adaptation of the prosthesisimplant interface by soldering golf cylinders to the framework casting. J Prosthet Dent. 1993;70:17-20.

22- Neo TK, Chai J, Gilbert JL, Wozniak WT, Engelman MJ. Mechanical properties of titanium connectors. Int J Prosthodont. 1996;9:379-93.

23- Rambhia SK, Nagy WW, Fournelle RA, Dhuru VW. Defects in hexed gold prosthetic screws: a metallographic and tensile analysis. J Prosthet Dent. 2002;87:30-9.

24- Riedy SJ, .Lang, BR, Lang BE. Fit of implant frameworks fabricated by different techniques. J Prosthet Dent. 1997;78:596604

25- Rubenstein, JE. Stereo laser-welded titanium implant frameworks Clinical and laboratory procedures with a summary of 1-year clinical trials. J Prosthet Dent. 1995;74:284-93.

26- Sartori IAM. Análise comparativa da interface intermediário estético/cilindro protético, torneados em ouro ou em plástico antes e após as fundições. Ribeirão Preto;1999. Faculdade de Odontologia de Ribeirão Preto da USP.

27- Schiffleger BE, Ziebert GJ, Dhuru VB, Brantley WA, Sigaroudi K. Comparison of accuracy of multiunit one-piece castings. J Prosthet Dent. 1985;54:770-6.
28- Wang RR, Chang CT. Thermal modeling of lasers welding for titanium dental restorations. J Prosthet Dent. 1998;79:335-42.

29- Wee AG, Aquilino AS, Scheneider, RL. Strategies to achieve fit in implant prosthodontics: a review of the literature. Int J Prosthodont. 1999;12:167-78.

30- Zoidis PC, Winkler S, Karellos ND. The effect of soldering, electrowelding and cast-to procedures on the accuracy of fit of cast implant bars. Implant Dent. 1996;5:163-8

31- Anusavice KJ. Phillips' Skinner Science of Dental Materials. St. Louis: W.B. Saunders Company; 1996 